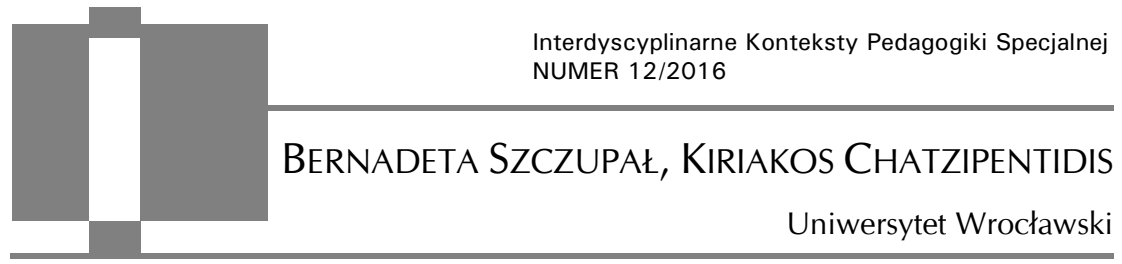

\title{
W poszukiwaniu drogi do emancypacji - godność osoby starszej i ageizm w świetle koncepcji praw człowieka oraz w perspektywie rozwoju współczesnego społeczeństwa
}

\begin{abstract}
Bernadeta Szczupał, Kiriakos Chatzipentidis, W poszukiwaniu drogi do emancypacji - godność osoby starszej i ageizm w świetle koncepcji praw człowieka oraz w perspektywie rozwoju wspótczesnego społeczeństwa [In search of the way to emancipation - the dignity of older persons and ageism in the light of the concept of human rights and in view of the development of modern society]. Interdyscyplinarne Konteksty Pedagogiki Specjalnej, nr 12, Poznań 2016. Pp. 99-118. Adam Mickiewicz University Press. ISSN 2300-391X
\end{abstract}

In this article we will present selected issues on the international protection of the dignity of the elderly and dignity as a human right in the internal legal order. We will also present danger to dignity of older persons in the contemporary social reality. We will show the complexity of the problems, expectations, and challenges faced by the elderly. We'll discuss situations that threaten their sense of dignity, as well as a conscious way of the elderly leading to the realization of this feeling, and we will draw attention to the prohibition of discrimination based on age in the general international law.

Keywords: dignity of older persons, ageism, concept of human rights 


\section{Wprowadzenie}

Populacja osób starszych stanowi zbiorowość niejednorodną pod wieloma względami, począwszy od stopnia zaawansowania starości, stanu zdrowia i zakresu zachowanej sprawności psychofizycznej, sytuacji socjalnej i ekonomicznej, miejsca zamieszkania aż po zakres wymaganego wsparcia ${ }^{1}$. Sytuacja osób starszych na tle globalnego zjawiska demograficznego starzenia się społeczeństw od lat stanowi przedmiot badań i analiz wielu ekspertów oraz instytucji (w tym Rzecznika Praw Obywatelskich, Instytutu Spraw Publicznych oraz Rządowej Rady Ludnościowej) poszukujących rozwiązań obecnych i przyszłych problemów, które wiążą się z niekorzystnymi zmianami struktury wieku ludności.

Zainteresowanie tematyką aksjologiczną - $\mathrm{w}$ tym godnością nabiera szczególnego znaczenia w odniesieniu do osób z niepełnosprawnością. Czas współczesny, obfitujący w znaczące zmiany polityczne, ekonomiczne oraz społeczne, czyni świat niepewnym i rodzi konieczność zmagania się z nieznanymi dotąd sytuacjami. W obecnej rzeczywistości społecznej, pomimo powszechnego uznawania znaczenia godności człowieka, zasadna jest refleksja nad respektowaniem godności osób starszych. W sferze deklaracji ich godność jest uznawana za istotną wartość oraz ważny cel działań mających na celu m.in. zapobieganie dyskryminacji, jednakże nadal zbyt mało podejmowanych jest działań, by kwestię godności realizować w praktyce. Godność pozostaje zawsze nadrzędnym punktem odniesienia, jest nieporównywalna $\mathrm{z}$ innymi wyznacznikami prawa i nie można jej zamienić na inne wartości. Godne traktowanie człowieka oznacza, że jest on w każdej życiowej sytuacji podmiotem, że ma wolność wyboru, nie może być wykorzystywany, a jego prawa muszą być respektowane. Godność człowieka wyraża się zapew-

${ }^{1}$ Organizacja Narodów Zjednoczonych uznaje, że do starszej części populacji należy zaliczać osoby powyżej 60 r.ż.. Również według Światowej Organizacji Zdrowia starość zaczyna się w 60 r.ż. WHO wyodrębnia wczesną starość (60-74 lata), późną starość (75-89 lat) oraz długowieczność (powyżej 90. r.ż) (por. B. Mikołajczyk, Międzynarodowa ochrona praw osób starszych, Wydawnictwo Wolters Kluwer Polska Sp. z o.o., Warszawa 2012, s. 34-35). 
nieniem mu autonomii, wolności i równości, w tym także w sferze praw ekonomicznych i socjalnych ${ }^{2}$. Niestety występują także zjawiska negatywne, które zmieniają funkcjonowanie rodzin, sposoby realizacji planów osób starszych, są powodem wykluczenia, marginalizacji i dyskryminacji, a więc stanowią zagrożenie podstawowej wartości, jaką jest poczucie własnej godności.

\section{Przemiany demograficzne}

Przełom lat 50. i 60. ubiegłego wieku zapoczątkował proces istotnych przemian demograficznych $w$ Europie, najwidoczniejszych $\mathrm{w}$ przekształceniach modelu rodziny, związanych $\mathrm{z}$ nią zmianach systemu wartości oraz organizacji życia. Jednym z najważniejszych rezultatów tych zmian jest zmiana zmniejszenie dzietności, prowadzące do zbyt niskiego przyrostu ludności. Opublikowana przez Główny Urząd Statystyczny w 2008 r. długookresowa prognoza demograficzna dla Polski i województw do roku 2035 zawiera założenia oraz analizę przewidywanych trendów zmian w przebiegu procesów demograficznych, kierunkach i rozmiarze ruchów migracyjnych oraz spodziewanych zmian $\mathrm{w}$ przebiegu procesów ludnościowych ${ }^{3}$. Dzięki rosnącej świadomości ludności dotyczącej sfery ochrony zdrowia, upowszechnieniu zdrowego stylu życia oraz zwiększeniu dostępności usług medycznych i opiekuńczych będzie następowało systematyczne obniżanie umieralności, którego tempo może jednak opóźniać szybkie starzenie się ludności. Do 2035 r. przeciętne trwanie życia kobiet osiągnie

2 T. Romer, Godność człowieka w prawie pracy i pomocy społecznej, [w:] Godność człowieka a prawa ekonomiczne i socjalne. Księga Jubileuszowa wydana w piętnasta rocznicę ustanowienia Rzecznika Praw Obywatelskich, Wydawnictwo Biura Rzecznika Praw Obywatelskich, Warszawa 2003, s. 59-83. B. Szczupał, Równość wobec prawa jako jeden $z$ warunków realizacji praw człowieka z niepetnosprawnością, „Niepełnosprawność półrocznik naukowy" 2009, nr 1, s. 149-155.

3 GUS, Prognoza ludności na lata 2008-2035 (Populationprojection for Poland 20082035), Główny Urząd Statystyczny, Departament Badań Demograficznych, Warszawa 2009, www.stat.gov.pl/gus/ [31.03.2016]. 
blisko 83 lata, w przypadku mężczyzn - ponad 77 lat. Natomiast urodzony w 2050 r. mężczyzna będzie miał przed sobą średnio 81,1 lat życia, a więc o 9 lat więcej niż w 2013 r., przeciętne trwanie życia kobiet wyniesie 87,5, czyli o 6,4 lat dłużej niż obecnie ${ }^{4}$. Niski poziom dzietności oraz wydłużanie się przeciętnego trwania życia pogłębia proces starzenia się społeczeństwa, niekorzystnie wpływając na zmiany w strukturze wieku ludności.

Zakładane szybkie starzenie się ludności (w roku 2035 odsetek osób w wieku 65 lat i więcej wyniesie $24,5 \%$ populacji, tj. ok. 8,358 mln osób. W roku 2050 udział procentowy ludności w wieku 65 lat i więcej w ogólnej liczbie ludności wyniesie 32,7\%). Obejmie on także tzw. podwójne starzenie, czyli znaczny wzrost udziału osób w wieku sędziwym (80 lat i więcej) - ich liczba do roku 2035 wzrośnie ponad dwukrotnie, do ok. 2,574 mln osób. W 2050 r. osoby ponad osiemdziesięcioletnie będą stanowiły aż 32\% zbiorowości osób starszych. Liczba ludności w wieku 80 lat wzrośnie w 2050 r. ponad dwukrotnie - do ponad 3,5 mln .

Osoby te, z racji wieku zazwyczaj wymagające wsparcia (jako najbardziej chorzy, niepełnosprawni i niesamodzielni), będą największym obciążeniem dla służby zdrowia, opieki oraz rodzin. Sytuacja szybkiego starzenia się ludności niesie także konkretne konsekwencje dla polityki społecznej, grożąc załamaniem się systemów: świadczeń rentowo-emerytalnych oraz usług zdrowotnych i opiekuńczych 6 .

Prognozowane zmniejszanie się podaży siły roboczej oraz szybkie starzenie się jej zasobów znacznie zwiększy obciążenie demograficzne - zmaleje liczba osób pracujących na przeciętnego emery-

${ }^{4}$ GUS, Sytuacja demograficzna osób starszych i konsekwencje starzenia się ludności Polski w świetle prognozy na lata 2014-2050, Główny Urząd Statystyczny, Departament Badań Demograficznych, Warszawa 2014, www.stat.gov.pl [31.03.2016].

5 Ibidem.

${ }^{6}$ B. Bień, Opieka zdrowotna nad ludźmi w starszym wieku. Stan a potrzeby w perspektywie starzenia się ludności Polski. „Biuletyn Rządowej Rady Ludnościowej” 2008, nr 53, s. 128-148. J. Hrynkiewicz, Starzenie się ludności polskiej a system ubezpieczeń społecznych, „Biuletyn Rządowej Rady Ludnościowej” 2008, nr 53, s. 9-25. 
ta oraz stanowiących wobec niego potencjał opiekuńczy z 4,04 osób obecnie do 2,16 osób w roku 2035. Liczba potencjalnych emerytów będzie mniejsza w stosunku do ich liczby przed zmianą ustawowego wieku emerytalnego w 2050 r. aż o 1/5 (o prawie 2,5 mln osób). Przy utrzymaniu poprzednich zasad dotyczących ustawowego wieku przejścia na emeryturę w 2050 r. na 100 osób w wieku produkcyjnym przypadałoby 75 osób uprawnionych do emerytury ${ }^{7}$. Według raportu Światowej Organizacji Zdrowia z 2015 r. świat stanął w obliczu dramatycznego wzrostu globalnej liczby osób starszych. Z danych szacunkowych wynika, że w 2050 r. w wielu krajach osoby powyżej 60. roku życia będą stanowić aż 30\% populacji. $\mathrm{W}$ ostatnich latach zmianie uległy nie tylko proporcje ale i tempo starzenia się społeczeństw, które jest o wiele większe niż w przeszłości (np. Francja przez 150 lat adaptowała się do zmiany udziału ludzi starszych w populacji z 10 do $20 \%$. Brazylia, Chiny i Indie mają na to tylko 20 lat) ${ }^{8}$. Wzrost obciążenia ludności w wieku produkcyjnym ludnością $\mathrm{w}$ wieku nieprodukcyjnym spowoduje obniżenie wartości współczynników potencjału wsparcia, określających zdolność, z jaką społeczeństwo może zapewnić nieformalne wsparcie osobom najstarszym.

\section{Dyskryminacja ze względu na wiek}

W sytuacjach, w których człowiek nie jest w stanie działać autonomicznie, niezbędne jest zapewnienie ochrony jego godności przez państwo, realizujące w tym zakresie postanowienia odpowiednich aktów legislacyjnych. Do realizacji zasad godności oraz równości wobec prawa, a co za tym następuje równości w traktowaniu przez instytucje publiczne, odnoszą się wszystkie współczesne akty

7 B. Bień, op. cit., s. 128-148; P. Błędowski, Ubezpieczenia społeczne - ryzyko niesamodzielności, „Biuletyn RPO” 2008, nr 65, s. 142-144; GUS, Sytuacja demograficzna osób starszych...

${ }^{8}$ WHO, World Report on Ageing and Health, World Health Organization, Luxembourg 2015. 
prawne dotyczące praw człowieka, zarówno międzynarodowe, jak również krajowe ${ }^{9}$. Niedopuszczalna jest jakakolwiek dyskryminacja (rasowa, ekonomiczna, społeczna, kulturowa, polityczna itp.). Ochrona godności i innych praw osób starszych jest realizacją wpisanych w Konstytucję Rzeczypospolitej Polskiej zasad sprawiedliwości społecznej, które są cechą praworządnego i sprawiedliwego państwa. Pomimo zakazu dyskryminacji wg art. 32 Konstytucji RP:

Wszyscy są wobec prawa równi. Wszyscy mają prawo do równego traktowania przez władze publiczne. Nikt nie może być dyskryminowany $\mathrm{w}$ życiu politycznym, społecznym lub gospodarczym z jakiejkolwiek przyczyny, osoby $\mathrm{w}$ starszym wieku nie zawsze są równo traktowane przez prawo, tak samo jak wszyscy obywatele. Istniejące normy mogą być źródłem barier w dostępie do ważnych dóbr i wartości oraz stanowić zagrożenie dla zaspokajania potrzeb przez osoby starsze, mogą narażać je na dyskryminację zwielokrotnioną (np. wieku, płci i niepełnej sprawności) ${ }^{10}$.

Dyskryminacja ze względu na wiek jest naruszeniem fundamentalnej zasady równości między ludźmi. Zjawisko to zostało określone angielskim mianem ageism ${ }^{11}$, którego polskim odpowiednikiem jest wiekizm, czyli

wyznawanie irracjonalnych poglądów i przesądów dotyczących jednostek lub grup opartych na ich wieku. Przyjmuje się stereotypowe założenia na temat fizycznych lub umysłowych cech ludzi z określonej grupy wiekowej i zwykle wyraża się je w sposób poniżający. Najczęściej wiekizm kieruje się przeciwko ludziom starym ${ }^{12}$.

${ }^{9}$ B. Mikołajczyk, op. cit.

${ }^{10}$ B. Szatur-Jaworska, Uczestnictwo osób starszych w sferze publicznej, „Biuletyn RPO" 2008, nr 65, s. 115-121.

11 Termin „ageism” utworzył w roku 1969 Robert Butler (1927-2010), amerykański gerontolog, opisując nim stosowanie negatywnych stereotypów, dyskryminacji z powodu wieku (R. Butler, Ageism: Another form of bigotry, "The Gerontologist" 1969, nr 91969; Coiner of the term "ageism" dead at 83, 2010, www.all-things-aging. com/2010/07/coiner-of-term-ageism-dead-at-83.html [31.03.2016]).

12 Stownik socjologii i nauk społecznych, red. G. Marshall, Wydawnictwo Naukowe PWN, Warszawa 2004, s. 421. 
Istnieje wiele przykładów dyskryminacji ludzi starszych, np. negatywne stereotypy dotyczące starości, kult młodości, powszechny brak rzetelnej wiedzy o starości, bezrobocie nasilające konkurencję na rynku pracy, specyficzne potrzeby wieku starszego, procedury, procedury dzielenia publicznych środków finansowych (np. z Narodowego Funduszu Zdrowia), niskie wykształcenie i osamotnienie ludzi starych, zła organizacja pracy instytucji obsługujących osoby starsze ${ }^{13}$.

W większości dokumentów legislacyjnych mających zastosowanie do osób starszych osoby te nie występują jako oddzielna kategoria uprawnionych, nie dysponują szczególnymi prawami ze względu na wiek. Należy jednak pamiętać, że nadmierna ochrona może rodzić efekt odwrotny do zamierzonego; poza tym specjalne prawa to narażenie na zarzut szczególnego traktowania ${ }^{14}$. W Polsce brakuje czytelnych zasad ochrony praw człowieka w starszym wieku (od lat wyraźnie formułowanych w dokumentach ONZ oraz Unii Europejskiej).

\section{Zabezpieczenie społeczne}

Obecny zakres podmiotowy świadczeń emerytalno-rentowych obejmuje wszystkie grupy społeczno-zawodowe, zaś zakres przedmiotowy świadczeń związanych z ryzykiem starości i niezdolności do pracy jest bardzo obszerny: emerytury, renty, zasiłki pielęgna-

${ }^{13}$ P. Szukalski, Uprzedzenia i dyskryminacja ze względu na wiek (ageizm) - przyczyny, przejawy, konsekwencje, „Polityka Społeczna” 2004, nr 2, s. 11-15.

${ }^{14}$ A. Bodnar, Dyskryminacja ze względu na wiek - regulacje prawne, Akademia Rozwoju Filantropii w Polsce, Projekt "Zysk z dojrzałości”, Warszawa 2008, www.bezuprzedzen.org/doc/Dyskryminacja_prawo_wiek.pdf [31.03.2016]; M. Chmaj, Równość wobec prawa, [w:] Wolności i prawa człowieka w Konstytucji Rzeczypospolitej Polskiej, red. M. Chmaj, Wydawnictwo WoltersKluwer, Warszawa 2008 s. 44-68; B. Szczupał, Równość wobec prawa jako jeden z warunków realizacji praw człowieka z niepetnosprawnościq, „Niepełnosprawność - półrocznik naukowy” 2009, nr 1, s. 149-155; E. Trafiałek, Rodzina i środowisko zamieszkania jako obszary ryzyka wykluczenia społecznego osób starszych, „Biuletyn RPO” 2008, nr 65, s. 79-94. 
cyjne itp. System emerytalny słabo respektuje zasadę równości ${ }^{15}$ : występuje zarówno nierówność sytuacji (wysokość emerytur określana jest według różnych zasad), jak też nierówność miar (zróżnicowane kryteria przyznawania uprawnień emerytalnych). Sytuacja wokół systemu zabezpieczenia społecznego może stanowić zagrożenie dla samodzielności: niski poziom świadczeń (emerytalnych bądź rentowych) nie gwarantuje zapewnienia właściwego poziomu bezpieczeństwa socjalnego. Brak jest poczucia pewności stabilizacji ubezpieczonych ${ }^{16}$. Również dotychczasowe działania na rzecz osób starszych odznaczają się różną skutecznością. W wielu środowiskach (np. wiejskich) praca socjalna z osobami w wieku podeszłym w ogóle nie jest prowadzona. Działania w tym zakresie prowadzone przez instytucje samorządowe, rządowe i organizacje pozarządowe, rzadko tworzą spójny system. Każdy podmiot działa według swoich własnych norm i sam decyduje, co jest najważniejsze dla zaspokajania podstawowych potrzeb osób starszych.

\section{Rynek pracy}

Dyskryminacja na rynku pracy ze względu na wiek może istnieć na dwóch poziomach. Poziom mezo (w przedsiębiorstwie) to m.in. ograniczenia rekrutacji ${ }^{17}$, brak inwestowania w kapitał ludzki (rzadsze delegowanie na kursy, wybór kursów krótszych, tańszych), niewielkie szanse na awans, naciski pracodawców na wcześniejsze odchodzenie na emeryturę (kryterium wieku, a nie doświadczenia i kompetencji), kwestie kultury organizacyjnej (etykietowanie). Poziom makro to kontekst społeczny, ekonomiczny i polityczny sto-

15 Zalecaną m.in. przez Rozporządzenie Parlamentu Europejskiego i Rady (WE) nr 883/2004 z dnia 29.04.2004 r. w sprawie koordynacji systemów zabezpieczenia społecznego (Regulation (EC) no 883/2004..., 2004).

16 P. Błędowski, Ubezpieczenia społeczne..., s. 142-144; J. Hrynkiewicz, op. cit., s. 9-25; A. Matysiak, Is Poland really 'immune' to the spread of cohabitation?, "Demographic Research" 2009, Vol. 21, s. 215-234

${ }^{17} \mathrm{~Np}$. „zatrudnię osobę w wieku do 40 lat" (zabronione w art. 11 i 18 Kodeksu pracy). 
sowania prawa: wysokie bezrobocie (główne działania nastawione na młodzież przebiegają z dezaktywacją zawodową osób starszych), niekonsekwencje systemu aktywizacji zawodowej, słabość sfery usług społecznych oraz słabość rynku elastycznych form pracy (zalecanych m.in. w Europejskiej strategii zatrudnienia) $)^{18}$.

W Polsce systematycznie wzrasta aktywność zawodowa osób powyżej 50. roku życia, szczególnie w grupie kobiet 60-64 lata, w której wzrost w latach 2013-2015 okazał się wyjątkowo silny. Należy również podkreślić, że w omawianym okresie (2013-2015) udział najstarszej grupy osób dokształcających się (55 lat i więcej) wykazał tendencję wzrostową, co stanowi kontynuację zmian zaobserwowanych w latach 2009-2013 ${ }^{19}$.

Praca stanowi ważny element rehabilitacji zawodowej i społecznej oraz służy integracji ze społeczeństwem, choć w praktyce często nadmiernie podkreśla się funkcje społeczne i terapeutyczne, niejako zapominając, że praca ma stanowić podstawowe źródło dochodów. Praca w istotnym stopniu kompensuje też wynikające z dysfunkcji ograniczenia i ma wpływ na poczucie godności i aktywność społeczną osób starszych.

\section{Ochrona zdrowia i opieka długoterminowa}

Raport Światowej Organizacji Zdrowia $\mathrm{WHO}^{20}$ wskazuje, że obecne podejście systemów służby zdrowia do starzenia się społeczeństw okazało się nieskuteczne. U osób powyżej 65. roku życia zanotowano zwiększone występowanie chorób przewlekłych, chorób współ-

${ }_{18}$ M. Góra, J. Liwiński, U. Sztanderska, Rekomendacje, [w:] Dezaktywizacja osób $w$ wieku okołoemerytalnym. Raport z badań, Ministerstwo Pracy i Polityki Społecznej, Departament Analiz Ekonomicznych i Prognoz, Warszawa 2008, s. 131-137; B. Szatur-Jaworska, op. cit., s. 115-121; P. Szukalski, Zagrożenia praw osób starszych na rynku pracy w Polsce, „Biuletyn RPO” 2008, nr 65, s. 19-35, 135-138.

19 Rynek pracy $i$ wykluczenie społeczne w kontekście percepcji Polaków Diagnoza Społeczna 2015, red. I.E. Kotowska, Ministerstwo Pracy i Polityki Społecznej, Rada Monitoringu Społecznego, Warszawa 2015.

${ }^{20} \mathrm{WHO}$, World Report on Ageing and Health... 
istniejących oraz niepełnosprawności. Według Światowego raportu na temat starzenia się $i$ zdrowia funkcjonujące modele opieki długoterminowej są nieadekwatne i niewystarczające. WHO zaleca, by w centrum nowych programów służby zdrowia znaleźli się ludzie starsi. Należy skupić się na unikalnych potrzebach osób starszych oraz aktywnie włączyć ich $\mathrm{w}$ procesy planowania opieki i zarządzania stanem zdrowia. Jedną z najważniejszych wytycznych World Report on Ageing and Health jest promocja praw osób starszych. Oznacza to całkowity brak akceptacji opieki nad osobą starszą, sprawowanej w sposób zdepersonalizowany, poniżający i przemocowy. Opieka długoterminowa powinna cechować się wspieraniem godności osoby starszej i jej autonomii oraz powinna wzmacniać poczucie wspólnoty ze społeczeństwem ${ }^{21}$.

W Polsce prawo do ochrony zdrowia jest wpisane $\mathrm{w}$ instytucjonalno-redystrybutywny model polityki społecznej22, zaś ochrona praw osób korzystających ze świadczeń zdrowotnych należy do obowiązków władz publicznych i wynika z bezpośredniego stosowania przepisów Konstytucji - artykuł 68:

Każdy ma prawo do ochrony zdrowia (ust. 1); Obywatelom, niezależnie od ich sytuacji materialnej, władze publiczne zapewniają równy dostęp do świadczeń opieki zdrowotnej finansowanej ze środków publicznych. Warunki i zakres udzielania świadczeń określa ustawa (ust. 2). Szczególne preferencje przyznano jednostkom słabszym: Władze publiczne są obowiązane do zapewnienia szczególnej opieki zdrowotnej dzieciom, kobietom ciężarnym, osobom niepełnosprawnym i osobom w podeszłym wieku (ust. 3).

Prawa pacjenta są uregulowane $\mathrm{w}$ wielu aktach prawnych; w roku 2009 weszła w życie ustawa o prawach pacjenta i Rzeczniku Praw Pacjenta, zawierająca katalog praw oraz ustanawiająca (art. 41) Rzecznika Praw Pacjenta. W praktyce realizacja zapisów legislacyj-

21 Ibidem.

22 T. Gardocka, Niektóre zagadnienia ochrony zdrowia na tle Konwencji bioetycznej i polskiego prawa medycznego, Medyczna Wokanda 2009, nr 1, s. 22-30. www.wil.org. pl/folder/biuletyn/wokanda_2010.pdf [31.03.2016]. 
nych dotyczących praw pacjenta napotyka na problemy związane zazwyczaj z dostępem do świadczeń medycznych i edukacji zdrowotnej. Często osoby starsze nie są w stanie wyegzekwować swoich praw. Godność pacjenta naruszają nie tylko niewłaściwe podejście lekarzy i personelu medycznego w trakcie realizowania świadczeń medycznych. Najważniejsze problemy wiążą się z dostępem do pomocy medycznej - długie oczekiwanie na przyjęcie przez specjalistę, wykonanie zabiegu, rehabilitację, zróżnicowanie możliwości oraz jakości leczenia w zależności od rejonu zamieszkania itp. Zgodnie z założeniami polityki społecznej dostęp do świadczeń finansowanych ze środków publicznych powinien być równy, lecz niestety - nie jest ${ }^{23}$.

Odsetek osób chorych, niesamodzielnych wzrasta wraz z wiekiem - około 50\% osób w wieku powyżej 70 lat staje się osobami $\mathrm{z}$ niepełnosprawnością, jednak informacje statystyczne nie zawsze odzwierciedlają stan faktyczny - wiele osób pozostaje poza ewidencją służb socjalnych ${ }^{24}$. Rodziny, które nie są w stanie zapewnić stałej opieki swoim chorym bliskim, zazwyczaj starają się umieścić ich w zakładach opiekuńczo-leczniczych (ZOL). Niestety, w instytucjach tych często dochodzi do łamania praw pacjenta.

Typowy pacjent geriatryczny ${ }^{25}$ to chory w późnej starości z wieloma procesami chorobowymi i zachodzacymi pomiędzy nimi interakcjami, zaś deficyty funkcjonalne powodują problemy w funkcjonowaniu całego organizmu (w sferze fizycznej, psychicznej oraz społecznej). W opiece zdrowotnej - nie tylko geriatrycznej - najistotniejsze są jej powszechność, dostępność, długotrwałość (ciągłość), jakość oraz kompleksowość (całościowe rozwiązywanie problemów w ramach interdyscyplinarnej współpracy lekarza, pielęgniarki, pracownika socjalnego). Potrzeba zapewnienia usług zdrowotnych i opiekuńczych rośnie wraz ze starzeniem się społeczeństwa, co objawia się geriatryzacją opieki zdrowotnejé ${ }^{26}$. Określenie to nie

\footnotetext{
23 Ibidem.

24 J. Hrynkiewicz, op. cit., s. 9-25. A. Matysiak, op. cit., s. 215-234.

${ }^{25}$ B. Bień, op. cit., s. 133.

${ }^{26}$ Ibidem, s. 139.
} 
oznacza fachowej opieki, wskazuje jedynie na potrzebę jej zapewnienia. Niestety, udział specjalistycznych świadczeń geriatrycznych, zorientowanych na całościową specyfikę potrzeb, a nie tylko na leczenie pojedynczych chorób, jest marginalny.

Zapotrzebowanie na świadczenia opiekunczo-pielęgnacyjne i socjalne realizowane w środowisku oraz w placówkach opiekunczych będzie systematycznie rosło $\mathrm{w}$ miarę narastania niekorzystnych zmian demograficznych. Od początku XXI w. obniża się współczynnik potencjału pielęgnacyjnego, określającego stosunek liczby typowych opiekunów osób wymagających stałego wsparcia do liczby osób w wieku 80 lat i więcej27. Za świadczenie i finansowanie opieki długoterminowej, oznaczającej nieokreślone w czasie świadczenie usług, pomocy i wsparcia dla przewlekle chorych lub niepełnosprawnych, w tym niedołężnych osób starszych, w krajach europejskich współodpowiedzialne są cztery sektory: rodzina wraz z siecią wsparcia nieformalnego, sektor opieki publicznej, organizacje pozarządowe i wolontariat oraz sektor prywatny. W Polsce dominującą formą jest opieka rodzinna, zaś w sytuacji braku rodziny bądź jej niewydolności opiekuńczej, do udzielania pomocy zobowiązane są formalne organizacje lub instytucje opiekuńcze ${ }^{28}$.

Konieczne jest wprowadzenie ubezpieczeń pielęgnacyjnych oraz sieci usług diagnostycznych, terapeutycznych, rehabilitacyjnych, pielęgnacyjno-opiekuńczych i usługowo-pomocowych. Opieka podstawowa, szpitalna i specjalistyczna, długoterminowa opieka instytucjonalna oraz domowa opieka usługowa $\mathrm{w}$ środowisku (w tym paliatywno-hospicyjna) powinna być zintegrowana; niestety utrudnia to odseparowanie resortu zdrowia od pomocy społecznej, które spowodowało pogorszenie działania zespołów opieki środo-

27 J. Derejczyk, B. Bień, J. Kokoszka-Paszkot, J. Szczygieł, Gerontologia i geriatria w Polsce na tle Europy - czy należy inwestować w ich rozwój w naszym kraju?, "Gerontologia Polska" 2008, tom 16, nr 3, s. 149-159.

28 B. Bień, op. cit., s. 128-148; A. Wilmowska-Pietruszyńska, J. Putz, Ubezpieczenie pielęgnacyjne jako propozycja rozwiązań systemowych potrzeb osób niezdolnych do samodzielnej egzystencji, „Postępy Nauk Medycznych” 2009, 4, s. 264-267. 
wiskowej (lekarz, pielęgniarka, pracownik socjalny)29. Niezależnie od wieku pacjenta, rodzaju schorzenia, system opieki zdrowotnej powinien zapewniać powszechną dostępność opieki medycznej (bez względu na jakiekolwiek różnicujące kryteria) oraz świadczenia profilaktyczno-lecznicze i rehabilitacyjne na możliwie najwyższym poziomie i o właściwej efektywności.

\section{Inne obszary dyskryminacji osób starszych}

Istotne znaczenie $\mathrm{w}$ istnieniu obszarów dyskryminacji oraz niesamodzielności mają także uwarunkowania osobiste wpływające na spadek aktywności społecznej i ekonomicznej osób starszych, w tym obowiązki rodzinne. Osoby starsze często są skazane na samotność, bezradność i niesamodzielność, jednakże brakuje rzetelnych danych na ten temat, $\mathrm{w}$ tym dotyczących problemów wewnątrzrodzinnych (np. przemocy), brakuje też odpowiednich regulacji prawnych ${ }^{30}$. Zbyt mała jest dostępność do informacji na temat należnych praw oraz pomocy (prawnej i społecznej) ${ }^{31}$.

Charakterystyczne dla osób w starszym wieku są: niewielki udział w życiu publicznym, małe zaangażowanie w pracę społeczną oraz ograniczony obszar społecznej komunikacji (w tym dostęp do nowoczesnych technologii) ${ }^{32}$.

Podobna sytuacja panuje na rynku dóbr i usług konsumpcyjnych: osoby starsze zbyt rzadko są traktowane jako wartościowa grupa docelowa na rynku, pomimo znaczącej siły nabywczej ${ }^{33}$.

29 J. Derejczyk, B. Bień, J. Kokoszka-Paszkot, J. Szczygieł, op. cit., s. 149-159.

30 Ustawa o przeciwdziałaniu przemocy w rodzinie z dnia 29 lipca 2005 r. nie traktuje osób starszych jako szczególnie narażonych na przemoc.

${ }^{31}$ M. Halicka, Przemoc wobec osób starszych, „Biuletyn RPO” 2008, nr 65, s. 95-110; E. Trafiałek, Rodzina i środowisko zamieszkania jako obszary ryzyka wykluczenia społecznego osób starszych, „Biuletyn RPO” 2008, nr 65, s. 79-94.

32 M. Halicka, op. cit., s. 95-110.

${ }^{33}$ GUS, Sytuacja demograficzna osób starszych...; Księga Ubogich a.d. 2009 IX Konwencja Ruchu przeciw Bezradności Społecznej, Cz. V: Ubóstwo ludzi starszych na podstawie sesji czwartej: "Przyjazne środowisko jako zabezpieczenie przed ubóstwem i wyklucze- 
Dysponują jednakże mniejszym zasobem informacji o prawach konsumenta, są podatne na informacje zawarte $w$ różnych formach reklamy, m.in. z powodu utrudnionego dostępu do informacji handlowej (ograniczony dostęp do internetu, mała czcionka na ulotkach i etykietach) z uwagi na ograniczenia budżetowe cena jest często jednym $\mathrm{z}$ głównych czynników decydujących o zakupie (zazwyczaj kosztem jakości). Stanowią także cel nieuczciwych działań, głównie podmiotów z branży sprzedaży bezpośredniej34.

\section{Przykłady realizacji założeń paradygmatu emancypacyjnego w odniesieniu do osób starszych}

We współczesnej literaturze dotyczącej osób starszych coraz częściej podejmowane są wątki autonomii, wolności, podmiotowości, kształtujące i umacniające paradygmat emancypacyjny tej grupy ${ }^{35}$. Emancypacja dokonuje się w wymiarze indywidualnym i społecznym, osobowym i historycznym ${ }^{36}$. O procesach emancypacyjnych świadczy reaktywny charakter różnych działań podejmowanych przez osoby starsze. W powstałym w ramach Diagnozy społecznej 2013 raporcie Aktywność społeczna osób starszych w kontekście percepcji Polaków autorzy jednoznacznie stwierdzają, że w Polsce osoby starsze spośród różnych form aktywności społecznej coraz bardziej świadomie angażują się w sprawy lokalnej społeczności (aż $71,7 \%$ osób w wieku emerytalnym regularnie uczestniczy w wyborach samorządowych) oraz w działania organizacji hobbystycznych,

niem osób starszych", red. E. Wrońska, Biuro Rzecznika Praw Obywatelskich, Ruch przeciw Bezradności Społecznej, Warszawa 2009, s. 582-664.

${ }^{34}$ P. Błędowski, Ubezpieczenia społeczne..., s. 142-144; P. Szukalski, Zagrożenia praw..., s. 19-35, 135-138.

${ }^{35} \mathrm{~J}$. Halicki, Obrazy starości rysowane przė̇yciami seniorów, Wydawnictwo Uniwersytetu w Białymstoku, Białystok 2010; B. Mikołajczyk, Międzynarodowa ochrona praw osób starszych, Wydawnictwo Wolters Kluwer Polska Sp. z o.o., Warszawa 2012.

${ }^{36}$ M. Czerepaniak-Walczak, Pedagogika emancypacyjna. Rozwój świadomości krytycznej człowieka, Gdańskie Wydawnictwo Psychologiczne, Gdańsk 2006. 
religijnych oraz upowszechniających wiedzę ${ }^{37}$. Autorzy raportu aktywność osób starszych podzielili na formalną i nieformalną. W ramach aktywności nieformalnej wyróżniają działania osób starszych na rzecz rodziny: 28,2\% osób (60-64 lata), 23,3\% (65-69 lat), 17,4\% (70-74 lata) czuje się odpowiedzialnych za zapewnienie opieki i dobrego samopoczucia rodzicom lub starszym krewnym, paradoksalnie $\mathrm{w}$ większym procencie niż respondenci $\mathrm{w}$ wieku 16-59 lat (15,3\%). W grupie $60-69$ lat $14,3 \%$ osób starszych angażuje się w prace na rzecz społeczności lokalnej i w wolontariat rozumiany jako nieodpłatnie wykonywane prace lub świadczenie usług dla osób spoza rodziny bądź na rzecz organizacji społecznej, mający charakter aktywności formalnej w ramach organizacji pozarządowej. Dla porównania w grupie 16-59 lat odsetek ten wynosi 16,5\%. Ogólna aktywność formalna osób > 60 r.ż. w organizacjach pozarządowych wynosi 7,4\%, czyli więcej niż w grupie $16-59$ lat $(6,8 \%)$. Zdecydowanie największy odsetek aktywnych społecznie osób starszych działa w organizacjach religijnych i kościelnych, dopiero później w organizacjach towarzyskich i klubach, kołach zainteresowan, komitetach mieszkańców, organizacjach upowszechniających wiedzę (Uniwersytety Trzeciego Wieku - UTW), związkach zawodowych, organizacjach pomocowych, organizacjach biznesowych, zawodowych, rolniczych, wybieranych władzach samorządowych, partiach politycznych, klubach sportowych, organizacjach ekologicznych, ośrodkach wsparcia i grupach samopomocowych ${ }^{38}$. Mężczyźni najczęściej działają w partiach politycznych, klubach sportowych, władzach samorządowych i kołach zainteresowań (np. myśliwskie, motoryzacyjne, wędkarskie). Natomiast zdecydowana większość kobiet udziela się w ośrodkach wsparcia i organizacjach pomocowych, towarzyskich, religijnych, komitetach mieszkańców i w Uniwersytetach III Wieku. Powyższe trendy nieznacznie zmieniły się w 2015 r. Osoby starsze najchętniej działały we władzach

37 J. Czapiński, P. Błędowski, Aktywność społeczna osób starszych w kontekście percepcji Polaków. Diagnoza społeczna 2013, Ministerstwo Pracy i Polityki Społecznej and Centrum Rozwoju Zasobów Ludzkich, Warszawa 2014, s. 65-72.

38 Ibidem. 
samorządowych, organizacjach upowszechniania wiedzy (głównie za sprawą uniwersytetów trzeciego wieku), organizacjach religijnych, towarzyskich i komitetach mieszkańców ${ }^{39}$. Poziom aktywności społecznej ludzi starszych okazał się wyższy niż młodszych pokoleń, zaś najważniejszym czynnikiem tej aktywności jest ich wykształcenie.

Emancypację seniorów można rozumieć jako ciągły dialog organów władzy ze społecznością osób starszych i wypracowanie takich mechanizmów komunikacji i wspólnego podejmowania decyzji, które będą skutkować coraz większą przejrzystością procesów podejmowania decyzji, wzrostem otwartości i wzajemnego zaufania ${ }^{40}$. W praktyce może ona przybierać wiele form. Jedną $\mathrm{z}$ nich są gminne rady osób starszych - rady o charakterze konsultacyjnym, doradczym i inicjatywnym. Składają się one z przedstawicieli osób starszych oraz przedstawicieli lokalnych podmiotów działających ich rzecz np. UTW ${ }^{41}$. Przykładami procesów emancypacyjnych z udziałem osób starszych mogą być również: spacery badawcze z osobami starszymi, fora seniorów, warsztaty przyszłościowe, panele obywatelskie z udziałem osób starszych, konsultacje programów dla seniorów, ustalanie kryteriów jakości usług opiekuńczych, projektowanie przestrzeni miejskiej z udziałem osób starszych.

\section{Zakończenie}

Powyższy przegląd jedynie sygnalizuje wybrane obszary dyskryminacji, wskazywane przez ekspertów zajmujących się problematyką osób starszych. Wielu autorów podnosi kwestię konieczności

39 J. Czapiński, T. Panek, Diagnoza Społeczna 2015. Warunki i jakość życia Polaków, Rada Monitoringu Społecznego, Warszawa 2015.

${ }^{40}$ Laboratorium Partycypacji Obywatelskiej, Jak ustyszeć głos seniora? Praktyczny przewodnik po partycypacji obywatelskiej osób starszych, Fundacja Pracownia Badań i Innowacji Społecznych „Stocznia”, Warszawa 2014.

41 W. Borczyk, D. Jachimowicz, W. Nalepa, Partycypacja osób starszych w życiu publicznym - wybrane zagadnienia, Ogólnopolska Federacja Stowarzyszeń Uniwersytetów Trzeciego Wieku, Nowy Sącz 2015. 
szybkiego zapewnienia efektywnych rozwiązań w: systemie ubezpieczeń społecznych, ochronie zdrowia, pomocy społecznej, polityce rodzinnej (pomoc rodzinom mogącym zapewnić opiekę osobom starym, w tym opiekę zastępczą), polityce zatrudnienia, systemie edukacji ustawicznej oraz polityce mieszkaniowej (mieszkalnictwo chronione). Ważne jest kształtowanie wzorów kultury wobec osób starszych budowanie obrazu medialnego wolnego od dyskryminacji, skierowanego na potencjał życiowy tej grupy osób, propagowanie dobrych praktyk oraz szerokie włączenie w aktywność społeczności lokalnych. Istotne znacznie ma również poczucie godności osób starszych, które pomaga ukierunkować ich życie pomimo zmiennych okoliczności, motywuje, wnosi poczucie sensu istnienia, wyznacza drogowskazy moralne, krystalizuje tożsamość, wzmacnia wierność ideałom i wartościom. Niezbędne jest więc podmiotowe traktowanie każdego człowieka, przyznające mu prawo do godności, szacunku, własnej odrębności i niepowtarzalności, przeciwdziałanie marginalizacji społecznej oraz szeroko rozumiana edukacja społeczna, mająca na celu przezwyciężanie uprzedzeń i stereotypów. Ważnym zadaniem pedagogów specjalnych jest promowanie postaw urzeczywistniających szacunek dla godności, wolności i równości człowieka starszego.

\section{Bibliografia}

Bień B., Opieka zdrowotna nad ludźmi w starszym wieku. Stan a potrzeby w perspektywie starzenia się ludności Polski. Rządowa Rada Ludnościowa, Biuletyn nr 53. Warszawa 2008.

Błędowski P., Ubezpieczenia społeczne - ryzyko niesamodzielności, [w:] Stan przestrzegania praw osób starszych w Polsce. Analiza i rekomendacje działań, red. B. SzaturJaworska, Biuro Rzecznika Praw Obywatelskich, Biuletyn RPO - Materiały nr 65, Warszawa 2008.

Borczyk W., Jachimowicz D., Nalepa W., Partycypacja osób starszych w życiu publicznym - wybrane zagadnienia, Ogólnopolska Federacja Stowarzyszeń Uniwersytetów Trzeciego Wieku, Nowy Sącz 2015.

Butler R., Ageism: Another form of bigotry, "The Gerontologist” 1969, nr 9.

Chmaj M., Równość wobec prawa, [w:] Wolności i prawa człowieka w Konstytucji Rzeczypospolitej Polskiej, red. M. Chmaj, Wydawnictwo Wolters Kluwer, Warszawa 2008. 
Czapiński J., Błędowski P. Aktywność społeczna osób starszych w kontekście percepcji Polaków. Diagnoza społeczna 2013, Ministerstwo Pracy i Polityki Społecznej and Centrum Rozwoju Zasobów Ludzkich, Warszawa 2014.

Czapiński J., Panek T., Diagnoza Społeczna 2015. Warunki i jakość życia Polaków, Rada Monitoringu Społecznego, Warszawa 2015.

Czerepaniak-Walczak M., Pedagogika emancypacyjna. Rozwój świadomości krytycznej człowieka, Gdańskie Wydawnictwo Psychologiczne. Gdańsk 2006.

Derejczyk J., Bień B., Kokoszka-Paszkot J., Szczygieł J., Gerontologia i geriatria w Polsce na tle Europy - czy należy inwestować w ich rozwój w naszym kraju?, "Gerontologia Polska, 2008" tom 16, nr 3.

Góra M., Liwiński J., Sztanderska U., Rekomendacje, w: Dezaktywizacja osób w wieku okołoemerytalnym. Raport z badań, Ministerstwo Pracy i Polityki Społecznej, Departament Analiz Ekonomicznych i Prognoz, Warszawa 2008.

Halicka M., Przemoc wobec osób starszych, w: Stan przestrzegania praw osób starszych w Polsce. Analiza i rekomendacje dziatań, red. B. Szatur-Jaworska, Biuro Rzecznika Praw Obywatelskich, Biuletyn RPO - Materiały nr 65, Warszawa 2008.

Halicki J., Obrazy starości rysowane przeżyciami seniorów., Wydawnictwo Uniwersytetu w Białymstoku, Białystok 2010.

Hrynkiewicz J., Starzenie się ludności polskiej a system ubezpieczeń społecznych, Rządowa Rada Ludnościowa, Biuletyn nr 53, Warszawa 2008.

Jak ustyszeć głos seniora? Praktyczny przewodnik po partycypacji obywatelskiej osób starszych, Laboratorium Partycypacji Obywatelskiej, Fundacja Pracownia Badań i Innowacji Społecznych "Stocznia”, Warszawa 2014.

Konstytucja Rzeczypospolitej Polskiej z dnia 2 kwietnia 1997 r. (Dz.U. z 1997 r. Nr 78, poz. $483 \mathrm{z}$ późn. zm.).

Ksiegga Ubogich a.d. 2009, IX Konwencja Ruchu przeciw Bezradności Społecznej, Cz. V: Ubóstwo ludzi starszych na podstawie sesji czwartej: „Przyjazne środowisko jako zabezpieczenie przed ubóstwem i wykluczeniem osób starszych", red. E. Wrońska, Biuro Rzecznika Praw Obywatelskich, Ruch przeciw Bezradności Społecznej, Warszawa 2009.

Matysiak A., Is Poland really 'immune' to the spread of cohabitation?, "Demographic Research" 2009, Vol. 21.

Mikołajczyk B., Międzynarodowa ochrona praw osób starszych., Wydawnictwo Wolters Kluwer Polska Sp. z o.o., Warszawa 2012.

Romer T., Godność cztowieka w prawie pracy i pomocy spotecznej. W: Godność człowieka a prawa ekonomiczne $i$ socjalne. Księga Jubileuszowa wydana w piętnasta rocznice ustanowienia Rzecznika Praw Obywatelskich. Wydawnictwo Biura Rzecznika Praw Obywatelskich, Warszawa 2003, s. 59-83.

Rynek pracy i wykluczenie społeczne w kontekście percepcji Polaków Diagnoza Spoteczna 2015, red. I.E. Kotowska, Ministerstwo Pracy i Polityki Społecznej, Rada Monitoringu Społecznego, Warszawa 2015.

Stownik socjologii i nauk społecznych, red., G. Marshall, Oxford, Wydawnictwo Naukowe PWN, Warszawa 2004. 
Strzelecki Z., Witkowski J., Przeszłość i perspektywy demograficzne Polski, Rządowa Rada Ludnościowa, Biuletyn nr 54, Warszawa 2009.

Szatur-Jaworska B., Uczestnictwo osób starszych w sferze publicznej, w: Stan przestrzegania praw osób starszych w Polsce. Analiza i rekomendacje dziatań, red. B. Szatur-Jaworska, Biuro Rzecznika Praw Obywatelskich, Biuletyn RPO - Materiały nr 65, Warszawa 2008.

Szczupał B., Równość wobec prawa jako jeden z warunków realizacji praw człowieka z niepetnosprawnościa, Niepetnosprawność - pótrocznik naukowy, nr 1: Teoretyczne i metodologiczne konteksty pedagogiki specjalnej, Fundacja Rozwoju Uniwersytetu Gdańskiego, Gdańsk 2009.

Szukalski P., Uprzedzenia $i$ dyskryminacja ze względu na wiek (ageizm) - przyczyny, przejawy, konsekwencje, „Polityka Społeczna” 2004, nr 2.

Szukalski P.,Zagrożenia praw osób starszych na rynku pracy w Polsce, w: Stan przestrzegania praw osób starszych w Polsce. Analiza i rekomendacje działań, red. B. Szatur-Jaworska, Biuro Rzecznika Praw Obywatelskich, Biuletyn RPO - Materiały nr 65, Warszawa 2008.

Trafiałek E., Rodzina i środowisko zamieszkania jako obszary ryzyka wykluczenia społecznego osób starszych, w: Stan przestrzegania praw osób starszych w Polsce. Analiza i rekomendacje działań, red. B. Szatur-Jaworska, Biuro Rzecznika Praw Obywatelskich, Biuletyn RPO - Materiały nr 65, Warszawa 2008.

Ustawa z dnia 26 czerwca 1974 r. Kodeks pracy (Dz.U. z 1998 r. Nr 21, poz. 94 z późn. zm.).

Ustawa z dnia 6 listopada 2008 r. o prawach pacjenta i Rzeczniku Praw Pacjenta (Dz.U. z 2009 r. Nr 52, poz. 417).

Ustawa z dnia 24 kwietnia 2009 r. Przepisy wprowadzające ustawę o prawach pacjenta i Rzeczniku Praw Pacjenta, ustawę o akredytacji w ochronie zdrowia oraz ustawę o konsultantach w ochronie zdrowia (Dz.U. z 2009 r. Nr 76, poz. 641).

Ustawa o przeciwdziałaniu przemocy w rodzinie z dnia 29 lipca 2005 r. (Dz.U. z 20 września 2005 r. z późn. zm.).

Wilmowska-Pietruszyńska A., Putz J. Ubezpieczenie pielegnacyjne jako propozycja rozwiązań systemowych potrzeb osób niezdolnych do samodzielnej egzystencji, „Postępy Nauk Medycznych" 2009, 4.

World Report on Ageing and Health, WHO, Luxembourg 2015.

\section{Źródła internetowe}

Bodnar A., Dyskryminacja ze względu na wiek - regulacje prawne, Akademia Rozwoju Filantropii w Polsce, Projekt „Zysk z dojrzałości”, Warszawa 2008 www.bezuprze dzen.org/doc/Dyskryminacja_prawo_wiek.pdf [31.03.2016].

Coiner of the term "ageism" dead at 83, 2010, www.all-things-aging.com/2010/07/ coiner-of-term-ageism-dead-at-83.html [31.03.2016]. 
Gardocka T., Niektóre zagadnienia ochrony zdrowia na tle Konwencji bioetycznej i polskiego prawa medycznego, „Medyczna Wokanda” 2009, nr 1, s. 22-30. www.wil.org. $\mathrm{pl} /$ folder/biuletyn/wokanda_2010.pdf [31.03.2016].

Polska 2030 - wyzwania rozwojowe, red. M. Boni, Kancelaria Prezesa Rady Ministrów, Zespół Doradców Strategicznych Prezesa Rady Ministrów, Warszawa 2009, www.zds.kprm.gov.pl [31.03.2016].

Prognoza ludności na lata 2008-2035 (Population projection for Poland 2008-2035), Główny Urząd Statystyczny, Departament Badań Demograficznych www.stat.gov. pl/gus/5840_5744_PLK_HTML.htm [31.03.2016].

Regulation (EC) no 883/2004 of the European Parliament and of the Council of 29 April 2004 on the coordination of social security systems, EN Official Journal of the European Union L 166/1, 30.4.2004, http:/ / eur-lex.europa.eu [31.06.2016].

Sytuacja demograficzna osób starszych i konsekwencje starzenia się ludności Polski w świetle prognozy na lata 2014-2050, Główny Urząd Statystyczny, Departament Badań Demograficznych, www.stat.gov.pl [31.03.2016]. 